\title{
Serum-starvation-induced changes in protein synthesis and morphology of Borrelia burgdorferi
}

\author{
P. Scott Alban, ${ }^{1}$ Paul W. Johnson ${ }^{2}$ and David R. Nelson ${ }^{1}$
}

Author for correspondence: David R. Nelson. Tel: +1 401874 5902. Fax: +1 4018742202.

e-mail: dnelson@uri.edu

Department of Biochemistry, Microbiology, and Molecular Genetics ${ }^{1}$, and Electron Microscope Facility2 ${ }^{2}$ University of Rhode Island, Kingston, RI 02881, USA

\begin{abstract}
It has been demonstrated previously that motile Borrelia burgdorferi cells transform into non-motile cyst-forms when incubated for several weeks in BSKII (a complex medium) lacking rabbit serum. B. burgdorferi cells cannot synthesize fatty acids de novo and serum is thought to provide a source of fatty acids and lipids. When $B$. burgdorferi cells were serum-starved in defined RPMI medium, $\sim 90 \%$ of the cells formed spherical cysts within $48 \mathrm{~h}$. Cyst formation was inhibited by tetracycline. Cyst opening and recovery of vegetative cells was rapidly induced by the addition of either BSKII or rabbit serum. The percentage of viable cells recovered from cysts ranged from $2.9 \%$ to $52.5 \%$. Viability was inversely proportional to cyst age. Protein synthesis by B. burgdorferi during serum starvation was examined by labelling cells with Tran ${ }^{35}$ S-Label and analysing the labelled proteins by two-dimensional gel electrophoresis and fluorography. The synthesis of over 20 proteins was induced during serum starvation. Western blots of proteins from vegetative cells and cysts probed with sera from either $B$. burgdorferi-infected humans or monkeys revealed that several cyst proteins were antigenic. These data suggest that cells of $B$. burgdorferi, although possessing a small genome and extremely limited biosynthetic capabilities, rapidly respond to conditions of serum starvation by inducing changes in protein synthesis and cell morphology. This study may help explain how cells of $B$. burgdorferi can survive periods of nutrient deprivation in different hosts and host tissues.
\end{abstract}

Keywords: Borrelia burgdorferi, spirochaete, serum starvation, cysts, Lyme disease

\section{INTRODUCTION}

Lyme disease, a multisystem illness, is a tick-borne bacterial disease caused by the spirochaete Borrelia burgdorferi (Burgdorfer et al., 1982). Following transmission of the spirochaetes to humans from ticks, Lyme disease can manifest itself in many different ways. Initially, the disease affects the skin, often with the development of a transient rash, erythema chronicum migrans. Other symptoms in the early stages of the disease can include fever, dizziness and chronic fatigue. Late-stage symptoms may include acute or chronic arthritis in large joints, meningoencephalitis, Bell's palsy, or myocarditis (Steere, 1989). B. burgdorferi cells have been isolated from the blood, cerebrospinal fluid

Abbreviations: CSF, cerebrospinal fluid; MPN, most probable number; SSP, serum starvation protein.
(CSF), synovial fluid and skin specimens of Lyme disease patients (Johnson \& Norton Hughes, 1992).

B. burgdorferi cells alternate between tick vectors (members of the Ixodes ricinus complex) and mammals. Therefore, these spirochaetes are adapted to survive in a number of different environments. Further, $B$. burgdorferi cells exhibit substantial changes in protein synthesis and gene expression and antigenicity during different stages of their zoonotic life cycle (Akins et al., 1998; Das et al., 1997; Fikrig et al., 1998; Schwan et al., 1995; de Silva et al., 1996; de Silva \& Fikrig, 1997). For example, two major outer-membrane proteins (OspA and $\mathrm{OspC}$ ) are differentially synthesized within the tick host. OspA is abundant on the surface of spirochaetes within the midguts of unfed ticks (de Silva et al., 1996) whereas OspC is more readily detected on the surface of spirochaetes in fed ticks (Schwan et al., 1995). Additionally, several B. burgdorferi genes appear to be 
expressed only within infected mammals (de Silva \& Fikrig, 1997; Akins et al., 1998; Suk et al., 1995).

Brorson \& Brorson (1997) demonstrated that cells of $B$. burgdorferi undergo a morphological transformation from motile spirochaetes into non-motile, spherical cyst-forms when incubated for $\sim 4$ weeks in BarbourStoenner-Kelly (BSKII) medium without the addition of rabbit serum, a routinely added media supplement thought to provide cells with a source of fatty acids (Barbour \& Hayes, 1986). Cyst-forms have also been observed in Lyme disease patient tissues (Hulinska et al., 1994; Aberer et al., 1997). It has been reported that these forms of $B$. burgdorferi are viable and capable of transforming back into motile spirochaetes, although survival was not accurately quantified (Brorson \& Brorson, 1997). The significance of these forms remains to be seen, but it has been suggested that cysts may represent a different stage in the life cycle of the spirochaetes or possibly play a role in human disease (Brorson \& Brorson, 1997, 1998a, b).

In the work described here, we studied cyst formation under defined conditions to determine: (1) the kinetics of cyst formation, (2) the viability of cyst-forms, and (3) whether cysts form as the result of a starvation-induced programme involving differential protein synthesis. Our study suggests that $B$. burgdorferi cells possess a complex starvation response that involves loss of motility, induction of protein synthesis, and morphological changes.

\section{METHODS}

Bacterial strains and culture conditions. The high-passage strain B. burgdorferi B31 and the low-passage strain T15 were routinely grown at $33^{\circ} \mathrm{C}$ in $10 \mathrm{ml}$ portions of BSKII broth (Barbour, 1984) in $16 \times 125 \mathrm{~mm}$ screw-capped tubes. BSKII is a complex medium that contains $6 \%$ rabbit serum in addition to other metabolites.

Serum starvation and recovery experiments. Exponentialphase cells $(50 \mathrm{ml})$ grown in BSKII medium were centrifuged (9000 $\mathrm{g}, 10 \mathrm{~min}$ ) at $4{ }^{\circ} \mathrm{C}$. Supernatants were removed and cells were resuspended in $80 \mathrm{ml}$ RPMI-1640 Select-Amine (RPMI) (Life Technologies). RPMI is a defined medium containing glucose, vitamins, and all 20 of the protein amino acids. Cultures were incubated at $33^{\circ} \mathrm{C}$ in $100 \mathrm{ml}$ screw-cap culture

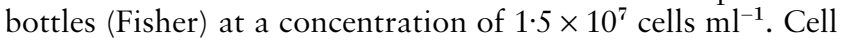
density was determined by phase-contrast microscopy using a haemocytometer (Reichart).

For the recovery experiments, exponential-phase cells were prepared and incubated in RPMI as described above. Viability of cells at various time points was determined by a three-tube most-probable-number (MPN) technique (American Public Health Association, 1975). Briefly, serum-starved cells (1 ml) were removed from RPMI by centrifugation $(14000 \mathrm{~g}, 1 \mathrm{~min})$, resuspended in BSKII $(1 \mathrm{ml})$, and serially diluted (serial tenfold dilutions) into BSKII. Each dilution was done in triplicate. Tubes $(1 \mathrm{ml})$ were incubated at $33^{\circ} \mathrm{C}$ for up to 2 weeks or until growth was observed, whichever was first. The percentage of recovery was estimated by a standard method (American Public Health Association, 1975).

Electron microscopy. Vegetative cells and cysts were fixed by the addition of EM-grade formaldehyde (1\% final concen- tration) to the culture medium. Fixed samples were centrifuged at $9000 \mathrm{~g}$ for $5 \mathrm{~min}$ and resuspended in $0.5 \mathrm{ml} 3 \%$ glutaraldehyde in $0 \cdot 1 \mathrm{M}$ sodium cacodylate buffer $(\mathrm{pH} 7 \cdot 2)$. Cells were mounted on 200-mesh carbon-coated grids and negatively stained with $1 \%$ phosphotungstic acid or $0.5 \%$ ammonium molybdate. The negatively stained preparations were examined and photographed using a JEOL 1200EX transmission electron microscope.

Radioactive labelling and protein precipitation. Exponentialphase cells $(50 \mathrm{ml})$ grown in BSKII were centrifuged $(9000 \mathrm{~g}$, $4{ }^{\circ} \mathrm{C}$ ) and resuspended as described above except that methionine was excluded in the formulation of RPMI. After the culture had been allowed to incubate at $33{ }^{\circ} \mathrm{C}$ for $5 \mathrm{~min}$, $10 \mu \mathrm{Ci} \mathrm{m} l^{-1}\left(370 \mathrm{kBq} \mathrm{m}^{-1}\right)$ of $\operatorname{Tran}^{35}$ S-Label (specific activity $43.48 \mathrm{TBq} \mathrm{mmol}{ }^{-1}$; ICN Pharmaceuticals) was added. Cells were labelled for either $2 \mathrm{~h}$ or up to $17 \mathrm{~h}$ in some cyst preparations where the low rate of incorporation required longer periods of labelling. Radioactive labelling was stopped by adding excess methionine $(10 \mathrm{mM})$. Labelled cells were then centrifuged $\left(9000 \mathrm{~g}, 10 \mathrm{~min}, 4^{\circ} \mathrm{C}\right)$ and washed twice in $10 \mathrm{mM}$ HEPES buffer $\left(\mathrm{pH} 7 \cdot 6,4^{\circ} \mathrm{C}\right)$. Cells were disrupted by sonication and protein was TCA-precipitated in order to concentrate the ${ }^{35} \mathrm{~S}$-labelled protein as described previously (Girouard et al., 1993; Scorpio et al., 1994). TCA-precipitated proteins were solubilized in solubilization-reduction mixture (Laemmli, 1970). Radioactive incorporation was determined by liquid scintillation counting of the solubilized protein.

Electrophoresis and Western blotting. Serum-starved (48 h) or exponential-phase cells grown in BSKII were centrifuged $(9000 \mathrm{~g}, 10 \mathrm{~min})$ and washed three times in $10 \mathrm{mM}$ HEPES buffer ( $\left.\mathrm{pH} 7 \cdot 6,4^{\circ} \mathrm{C}\right)$. Cells were disrupted by sonication and protein concentrations in unlabelled cell extracts were estimated by the method of Bradford (1976) with a Bio-Rad protein assay kit.

One-dimensional SDS-PAGE was performed in $1.5 \mathrm{~mm}$ thick slab gels (5\% stacking, 10-13\% separating) as described by Laemmli (1970), using an SE 600 vertical electrophoresis unit. Equal protein $(20 \mu \mathrm{g})$ was loaded in each gel lane. The separated proteins were either stained with Coomassie blue or electroblotted to nitrocellulose by a modification of the procedure described by Towbin et al. (1979) using a Bio-Rad Transblot Cell (400 mA, $60 \mathrm{~min}$ ) (Girouard et al., 1993). The nitrocellulose membranes were briefly stained with $0 \cdot 1 \%$ Ponceau S (Sigma) to mark the positions of molecular mass standards and then blocked in Tris-buffered saline (TBS: $50 \mathrm{mM}$ Tris, $150 \mathrm{mM} \mathrm{NaCl}$; pH 7.4) plus $2 \%$ Tween 20 (Sigma) for $20 \mathrm{~min}$. The membranes were washed twice for $5 \mathrm{~min}$ in TBS $+0.05 \%$ Tween 20. The transferred proteins were reacted overnight at $4{ }^{\circ} \mathrm{C}$ with sera from $B$. burgdorferiinfected rhesus monkeys (L913 or K205) (Philipp et al., 1993; Roberts et al., 1998), from a chronically infected Lyme disease patient $(\mathrm{J} 1)$, or with monoclonal antibodies at the appropriate dilution (see figure legends) in TBS plus $0.05 \%$ Tween 20. Monkey sera and patient sera were generous gifts of Mario Philipp (Tulane Regional Primate Research Center, Covington, LA, USA) and Thomas Mather (University of Rhode Island), respectively. Mouse monoclonal antibodies H9724, H5332, 4B8F4 and 149, specific for flagellin, OspA, OspC and GroEL, respectively, were kindly provided by Barbara Johnson (Division of Vector-Borne Diseases, $\mathrm{Ft}$ Collins, CO, USA).

Proteins were separated by isoelectric focusing (IEF) using the Multiphor II system (Pharmacia) with Immobiline DryStrips ( $\mathrm{pH} 3-10)$ according to the manufacturer's protocol. Equal radioactive counts of ${ }^{35} \mathrm{~S}$-labelled proteins (solubilized after TCA precipitation) were loaded onto IEF gels and gels were 
run to equilibrium at $20{ }^{\circ} \mathrm{C}$. IEF gels were then incubated for $10 \mathrm{~min}$ in equilibrium buffer $(50 \mathrm{mM}$ Tris $\mathrm{pH} 8 \cdot 8,6 \mathrm{M}$ urea, $30 \%, \mathrm{v} / \mathrm{v}$, glycerol, $2 \%$ SDS) before being loaded onto a vertical SDS-PAGE gel. Vertical electrophoresis (the second dimension) was performed using the SE 600 apparatus as described above. Separated proteins were visualized by fluorography as previously described (Carreiro et al., 1990). Dried gels were exposed to Fuji RX film (Fisher) at $-70^{\circ} \mathrm{C}$ for 3-7 d. Fluorograms were analysed by laser densitometry using a Molecular Dynamics Personal Densitometer (Molecular Dynamics) and Image QuaNT v.5.0 software, as previously described (Garcia et al., 1997).

MALDI-MS protein identification. Following two-dimensional PAGE separation of labelled proteins and autoradiography, the protein corresponding to serum starvation protein s (SSP s) was cut from the gel and subjected to in-gel trypsin digestion and MALDI-MS protein identification as described by Williams et al. (1996).

\section{RESULTS}

\section{Morphological transformation to cysts during serum starvation}

In a recent study, Brorson \& Brorson (1997) demonstrated that $B$. burgdorferi cells transform from vegetative spirochaetes into spherical 'cyst-forms' when incubated in BSKII medium lacking rabbit serum (BSKII-S). We confirmed these observations. Usually, $30-50 \%$ of cells incubated in BSKII $-S$ formed cyst-like structures over 2-4 weeks. However, BSKII is not a defined medium and does contain BSA (fraction V, $50 \mathrm{~g}$ $\left.1^{-1}\right)$. In an effort to better define cyst formation as a response to serum or fatty acid starvation, B. burgdorferi B31 cells were incubated in RPMI. One hour after the onset of serum starvation, cells lost normal motility at one or both poles and began twisting into knots. Within $24 \mathrm{~h}$, cells starved of serum were completely non-motile and $30-40 \%$ had begun to encyst. After $48 \mathrm{~h}$ incubation in RPMI, $\sim 90 \%$ of serum-starved cells had formed cysts (Fig. 1). In contrast, control cells incubated in RPMI plus $6 \%$ rabbit serum $(\mathrm{RPMI}+\mathrm{S})$ remained motile and no cysts were observed. Additionally, while spirochaetes incubated in RPMI $+\mathrm{S}$ decreased the $\mathrm{pH}$ of the medium from $7 \cdot 6$ to $6 \cdot 8$, those incubated in RPMI decreased the $\mathrm{pH}$ from $7 \cdot 6$ to $7 \cdot 3$. Cells incubated in $\mathrm{RPMI}+\mathrm{S}$ became non-motile after $5-6 \mathrm{~d}$ but did not form cysts. Comparable cyst formation was also observed when the low-passage strain T15 was used; therefore, all subsequent experiments were performed using high-passage strain B31. Cyst formation was inhibited by the addition of tetracycline $(150 \mu \mathrm{g}$ $\mathrm{ml}^{-1}$ ) to RPMI.

Negatively stained preparations of B. burgdorferi cysts were observed by electron microscopy and compared to vegetative cells (Fig. 1). In contrast to typical helical vegetative cells, most $48 \mathrm{~h}$ serum-starved cells were coiled within a membrane. The overall shape was roughly spherical, often with one end of the coiled spirochaete protruding (Fig. 1C). Additionally, we sometimes observed portions of outer membrane 'beading' away from a pole of the cell (Fig. 1C).

\section{Determination of viability during serum starvation}

When rabbit serum or BSK was added to RPMI containing $48 \mathrm{~h}$ serum-starved cells, the cysts opened within $10 \mathrm{~s}$ to yield intact, but non-motile spirochaete cells (Fig. 2). A newly emerged spirochaete with an empty cyst is shown in Fig. 2C. Cysts did not open when $20 \%$ sucrose was added to the culture. Cells began to regain motility $12-15 \mathrm{~h}$ after emerging from the cysts. Since $\mathrm{RPMI}+\mathrm{S}$ is not a growth medium for $B$. burgdorferi, viability experiments were performed by MPN determinations in BSKII as described in Methods. The data presented in Table 1 show that B. burgdorferi cells could be grown from cultures starved for serum for up to $8 \mathrm{~d}$. Cells starved for 2 weeks were not recoverable even after $>30 \mathrm{~d}$ incubation in BSKII. In contrast, no viable cells could be recovered by $5 \mathrm{~d}$ from cultures incubated in $\mathrm{RPMI}+\mathrm{S}$, nor could viable cells be recovered from cultures starved in HEPES buffer after

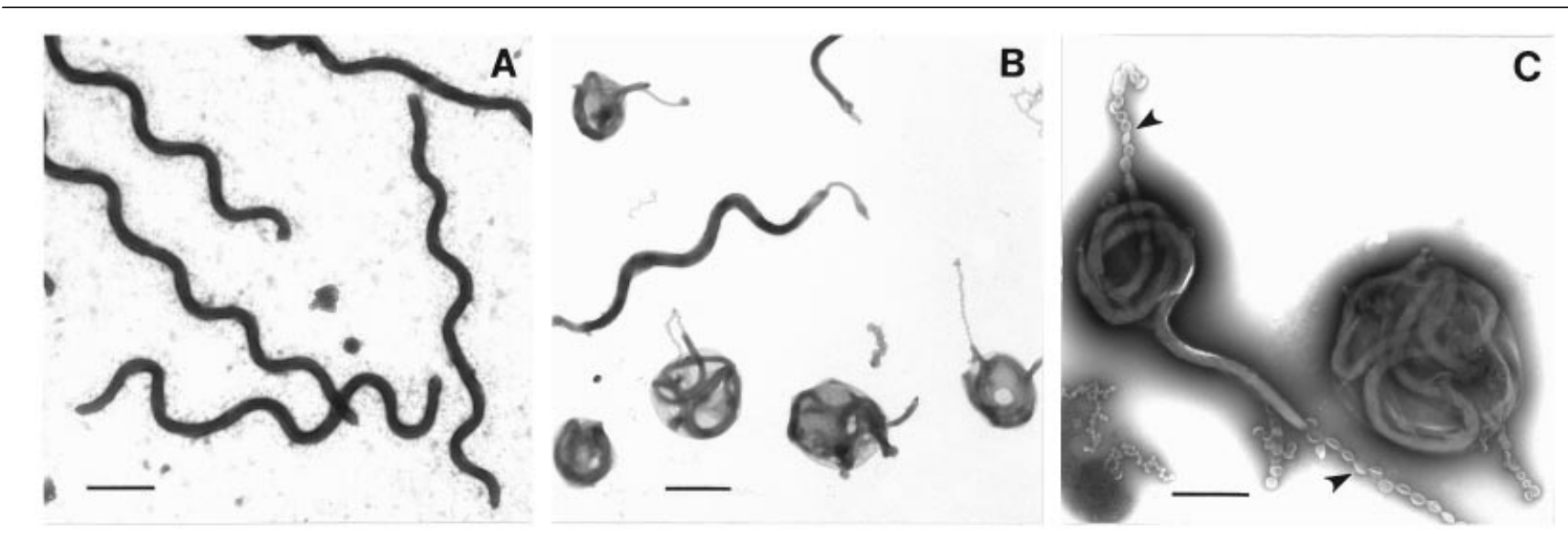

Fig. 1. Transmission electron micrographs demonstrating cyst formation of $B$. burgdorferi in response to serum starvation. A, Typical vegetative spirochaetes observed in BSKII or RPMI $+\mathrm{S}$. B, C, Cyst forms occurring after $48 \mathrm{~h}$ incubation in RPMI. Arrowheads indicate membrane 'beading'. Bars, $2 \mu \mathrm{m}$ (A and B); $1 \mu \mathrm{m}$ (C). 

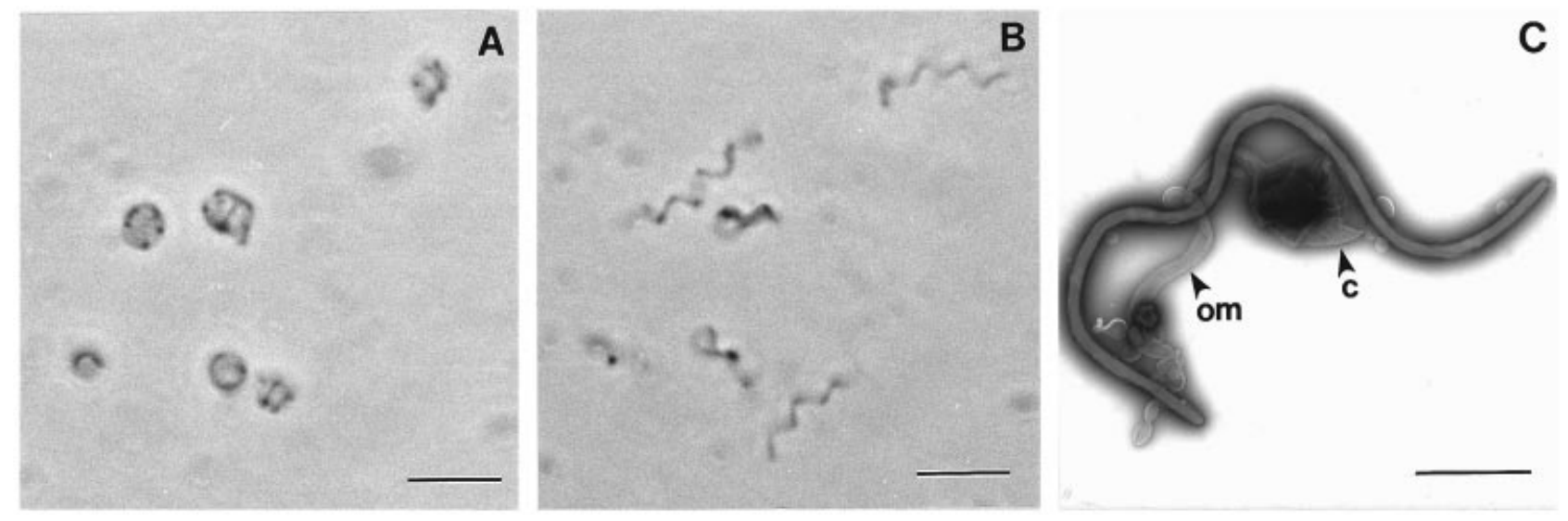

Fig. 2. Morphology of $B$. burgdorferi in a $48 \mathrm{~h}$ serum-starved culture before $(A)$ and after $(B$ and $C$ ) addition of rabbit sera. Panels $A$ and $B$ are phase-contrast micrographs that show identical fields, allowing the comparison of individual cells. Panel $B$ was photographed $<1$ min after the addition of rabbit serum. Panel $C$ is a transmission electron micrograph showing a newly emerged spirochaete. Arrowheads indicate an empty cyst (c) and an outer membrane (om). Bars, $5 \mu \mathrm{m}$ (A and $B) ; 2 \mu \mathrm{m}(\mathrm{C})$.

Table 1. Recovery of viable cells

Recovery of viable cells was determined by MPN analysis as described in Methods.

\begin{tabular}{|lccc|}
\hline Medium & Time $(\mathbf{d})$ & $\begin{array}{c}\text { Percentage } \\
\text { viability } \pm \mathrm{SD}^{*}\end{array}$ & Motility $\dagger$ \\
\hline RPMI & 0 & $100 \cdot 0 \pm 0$ & + \\
& 2 & $52 \cdot 5 \pm 13 \cdot 4$ & - \\
& 3 & $18 \cdot 2 \pm 12 \cdot 5$ & - \\
& 5 & $15 \cdot 7 \pm 12 \cdot 5$ & - \\
RPMI $+\mathrm{S}$ & 8 & $2 \cdot 9 \pm 1 \cdot 9$ & - \\
& 0 & $100 \cdot 0 \pm 0$ & + \\
& 2 & $56 \pm 8 \cdot 5$ & + \\
HEPES & 5 & $0 \pm 0$ & - \\
& 0 & $100 \cdot 0 \pm 0$ & - \\
\hline
\end{tabular}

* Percentage viability $=($ viable cells as determined by MPN technique)/(direct microscopic count at $t=0)$. The data shown are averaged from two independent experiments.

† Motility was determined by microscopic observation prior to MPN experiments.

$1 \mathrm{~d}$ (Table 1). It is important to note that spirochaetes incubated in HEPES buffer or distilled water formed round cells that clumped together. These structures resembled spheroplasts and were repeatedly demonstrated to be nonviable by MPN determinations.

\section{Protein synthesis during serum starvation}

Changes in protein synthesis by B. burgdorferi cells during serum starvation were determined by labelling cells with $\operatorname{Tran}^{35}$ S-Label and analysing the labelled proteins by two-dimensional gel electrophoresis and fluorography. Proteins from serum-starved cells (labelled at $t=0-2 \mathrm{~h}$ and $2-19 \mathrm{~h}$ ) were compared to proteins labelled in RPMI $+\mathrm{S}(t=0-2 \mathrm{~h})$. Protein synthesis patterns observed by two-dimensional gel electrophoresis in RPMI $+\mathrm{S}(t=0-2 \mathrm{~h})$ were similar to those observed when cells were labelled in BSKII for $18 \mathrm{~h}$. Examination of two-dimensional fluorograms revealed that over 20 proteins were induced in serumstarved cells (Fig. 3). The approximate molecular masses and $\mathrm{pI}$ values of proteins induced at least twofold during serum starvation are listed in Table 2 . The positions of known antigens (OspA, Fla, OspC, GroEL) identified by monoclonal antibodies are also indicated in Fig. 3. Of the identified antigens, only OspA appeared to be upregulated during serum starvation. Examination of the fluorograms presented in Fig. 3 revealed that there was a time-dependent synthesis of proteins after the initiation of serum starvation. Several serum-starvation proteins (SSPs) were synthesized early $(t=0-2 \mathrm{~h})$ during starvation (e.g. SSP e, j, m, n, o, u, v). Other SSPs were synthesized predominantly at later times during starvation (e.g. SSP a, c, f, h, q, s, t). One SSP (SSP s) was identified by MALDI-MS as a homologue of VlsE (Table 2 ), a protein shown to be involved in antigenic variation of B. burgdorferi cells (Zhang et al., 1997).

\section{Antigenicity of cyst proteins}

Whole-cell protein extracts from vegetative cells and $48 \mathrm{~h}$ cysts were separated by SDS-PAGE, electroblotted onto nitrocellulose, and probed with sera from Lymedisease-infected patients or monkeys. Representative Western blots probed with sera from monkeys with either early stage (L913) or late-stage (K205) Lyme disease (Philipp et al., 1993), or with serum from a chronically infected human patient (J1) are shown in 


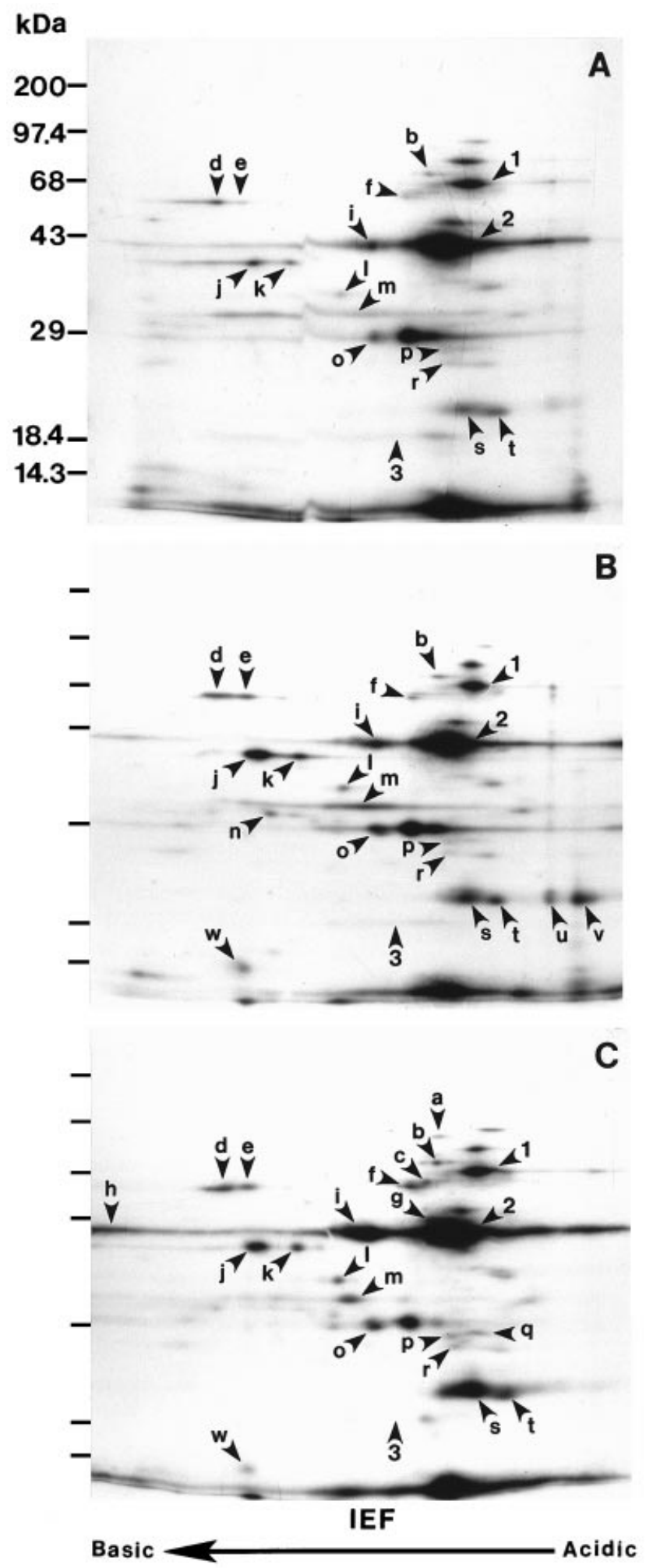

Fig. 3. Two-dimensional fluorograms of proteins synthesized in: A, RPMI $+\mathrm{S}, t=0-2 \mathrm{~h} ; \mathrm{B}, \mathrm{RPMl}, t=0-2 \mathrm{~h}$; and C, RPMI, $t=$ $2-19 \mathrm{~h}$. Lower-case letters indicate the location of induced proteins. The positions of known protein antigens, GroEL, flagellin and $\mathrm{OspC}$, determined by two-dimensional Western blots using monoclonal antibodies (1:5000 dilution) are indicated by numbers 1,2 and 3 , respectively. The position of another known antigen, OspA, is indicated by the letter ' $O$ ' as
Table 2. Proteins induced in response to serum starvation

\begin{tabular}{|c|c|c|c|c|}
\hline \multirow[t]{2}{*}{$\begin{array}{l}\text { Induced } \\
\text { SSP* }\end{array}$} & \multirow[t]{2}{*}{$\begin{array}{l}\text { Mol mass } \\
\qquad(\mathrm{kDa})\end{array}$} & \multirow[t]{2}{*}{ pI } & \multicolumn{2}{|c|}{$\begin{array}{c}\text { Relative induction } \\
\text { in RPMI } \dagger\end{array}$} \\
\hline & & & $0-2 \mathrm{~h}$ & $2-19 \mathrm{~h}$ \\
\hline $\mathrm{a}$ & 89 & $5 \cdot 8$ & 0 & + \\
\hline $\mathrm{b}$ & 66 & $5 \cdot 9$ & 0 & + \\
\hline c & 58 & $6 \cdot 0$ & 0 & + \\
\hline d & 57 & $8 \cdot 4$ & 0 & + \\
\hline e & 57 & $8 \cdot 1$ & + & + \\
\hline $\mathrm{f}$ & 57 & $6 \cdot 1$ & + & + \\
\hline g & 43 & $5 \cdot 9$ & 0 & + \\
\hline $\mathrm{h}$ & 41 & 10 & 0 & + \\
\hline i & 41 & $6 \cdot 7$ & 0 & + \\
\hline j & 37 & $7 \cdot 9$ & + & + \\
\hline $\mathrm{k}$ & 37 & $7 \cdot 4$ & + & + \\
\hline 1 & 34 & $7 \cdot 0$ & + & + \\
\hline $\mathrm{m}$ & 32 & 6.9 & + & + \\
\hline $\mathrm{n}$ & 31 & $7 \cdot 7$ & + & 0 \\
\hline oł & 29 & $6 \cdot 9$ & + & + \\
\hline $\mathrm{p}$ & 28 & $5 \cdot 7$ & 0 & + \\
\hline $\mathrm{q}$ & 28 & $5 \cdot 7$ & 0 & + \\
\hline $\mathrm{r}$ & 27 & $5 \cdot 7$ & 0 & + \\
\hline$s \neq$ & $24 \cdot 5$ & $5 \cdot 5$ & + & + \\
\hline t & 24 & $5 \cdot 0$ & + & + \\
\hline $\mathrm{u}$ & 24 & $4 \cdot 3$ & + & 0 \\
\hline $\mathrm{v}$ & 24 & $4 \cdot 0$ & + & 0 \\
\hline $\mathrm{w}$ & $13 \cdot 5$ & $8 \cdot 0$ & + & + \\
\hline
\end{tabular}

* Proteins are designated by lower-case letters $(\mathrm{a}-\mathrm{w})$ as shown in Fig. 3.

† Relative induction of SSPs determined by comparison of twodimensional fluorograms of proteins from cells incubated and labelled in RPMI and RPMI + S. Induced proteins are indicated by $(+)$; proteins synthesized at similar or reduced levels are indicated by $(0)$. Determinations were based on at least three separate trials for each time point.

‡SSP o and SSP s have been identified as OspA and a VlsE homologue, respectively.

Fig. 4. While Coomassie-blue-stained SDS gels prepared from vegetative cells or cysts were virtually indistinguishable (data not shown), the Western blots displayed consistent differences between the protein antigens recognized in vegetative cells and cysts. For example, several low-molecular-mass bands $(\sim 16-25 \mathrm{kDa})$ were consistently more reactive in cyst preparations. Additionally, examination of two-dimensional fluorograms showed that four proteins in the $16-25 \mathrm{kDa}$ range were upregulated in cysts (Fig. 3). These two observations suggested that some or all of these low-molecular-mass proteins might be identical and antigenic. Preliminary

it is one of the induced proteins. The molecular mass standards, identified in $\mathrm{kDa}$ in panel $\mathrm{A}$, are indicated in panels $B$ and $C$ by their location only. 


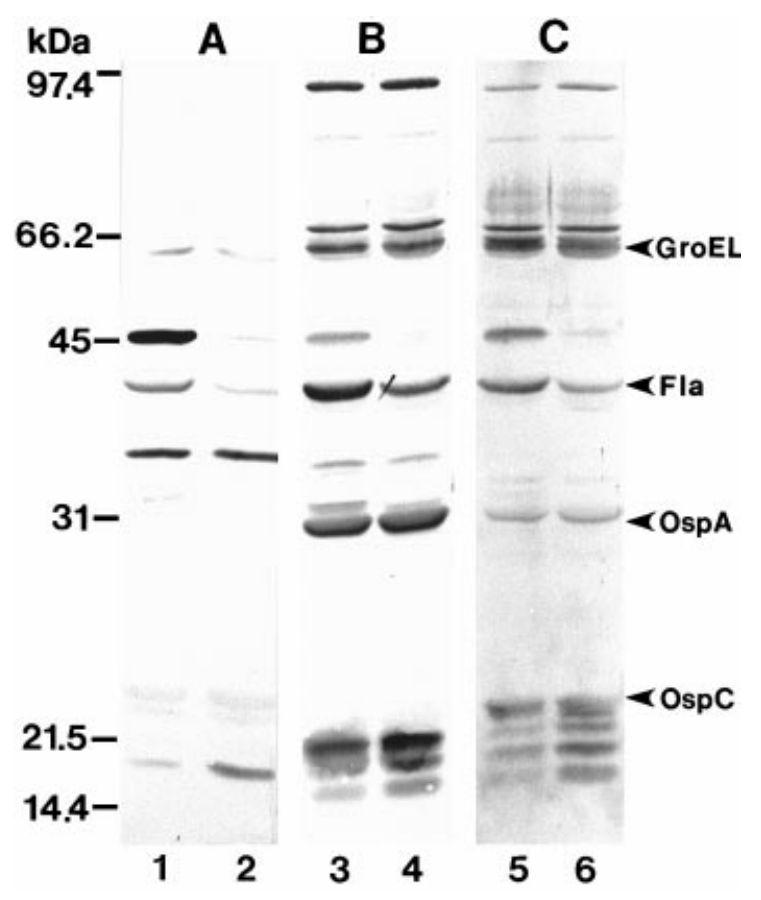

Fig. 4. Western blots of $B$. burgdorferi proteins from vegetative cells $(1,3,5)$ and serum-starved cells $(2,4,6)$ reacted with sera from monkeys with either early-stage (L913) or late-stage (K205) Lyme disease (Philipp et al., 1993) (panels A and B, respectively), or with serum from a chronically infected human patient (J1) (panel C). The monkey sera and human sera were diluted $1: 2000$ and $1: 2500$, respectively. The positions of known antigens GroEL, Flagellin, OspA and OspC are indicated by arrows; they were detected with monoclonal antibodies (1:5000 dilution).

two-dimensional Western blots showed that at least two of these proteins were recognized by serum from a chronically infected monkey (data not shown). In contrast, both the $46 \mathrm{kDa}$ and $41 \mathrm{kDa}$ (flagellin) protein bands exhibited less reactivity to sera from humans or monkeys in blots prepared from cysts, suggesting that both proteins were present in decreased amounts in cysts.

\section{DISCUSSION}

B. burgdorferi grows in both tick and mammalian hosts during its infection cycle. The ability to survive and grow in disparate hosts clearly displays the adaptability of this microbe. B. burgdorferi possesses a genome of only $\sim 1000 \mathrm{kbp}$, encoding very limited biosynthetic capabilities (Fraser et al., 1997). The lack of many biosynthetic pathways explains why growth in vitro requires a complex medium supplemented with animal serum (BSKII). The serum is thought to provide the cells with a source of fatty acids, since they lack the ability to synthesize fatty acids de novo (Fraser et al., 1997). It is not yet known how these fastidious organisms survive periods of starvation such as that encountered during the tick moult, between tick blood meals. In this report, we demonstrate that B. burgdorferi cells respond to serum starvation by inducing a starvation response that results in the transformation of motile helical vegetative cells into non-motile, spherical cysts containing tightly coiled spirochaetes. This starvation-response programme also includes the coordinated synthesis of over 20 proteins. Some of these proteins are antigenic in mammalian hosts.

It has previously been reported that $B$. burgdorferi spirochaetes develop into cysts in vitro when they are incubated either in BSKII - S for several weeks (Brorson \& Brorson, 1997) or in CSF $\left(37^{\circ} \mathrm{C}\right)$ for $24 \mathrm{~h}$ (Brorson \& Brorson, 1998a). We began our study by observing cyst formation in BSKII - S. We estimate that only $30-50 \%$ of the cells transform into cysts after 4 weeks. We hypothesize that cells form cysts in response to starvation for serum or the abundant fatty acids and lipids in serum. Slow formation of cysts in BSKII-S is probably due to the presence of some fatty acids or lipids in the large amount of BSA $\left(50 \mathrm{~g} \mathrm{l}^{-1}\right)$ in the medium. We thought that elimination of all fatty acids and lipids from the medium would increase both the rate of cyst formation and the percentage of cells which undergo the transformation. Using RPMI without the addition of serum, cells become non-motile within a few hours and $90 \%$ of vegetative spirochaetes form cysts within $48 \mathrm{~h}$. A cyst appears to contain an intact, coiled non-motile spirochaete within a membrane (Fig. 1). It is unclear whether the membrane is part of the original outer membrane of the vegetative cell or whether it is constructed during cyst formation.

Cyst formation is an active cellular response to serum starvation. The addition of tetracycline inhibits cyst formation, demonstrating that cyst formation requires protein synthesis and that cysts are not merely degenerative forms. Further, the temporal pattern of protein synthesis during cyst formation strongly suggests that encystment is a global response to a specific starvation (see Fig. 3 and Table 2). Additionally, cysts are able to survive longer than $B$. burgdorferi cells incubated in either similar media plus serum or buffer alone (Table 1). In contrast to a recent report that describes rapid cyst formation in distilled water (Brorson \& Brorson, 1998b), we did not observe the formation of viable cysts in HEPES or distilled water. We did observe that B. burgdorferi incubated for more than $1 \mathrm{~h}$ in distilled water or HEPES buffer formed rounded, clumping, spheroplast-like cells, but these structures were consistently shown to be nonviable by quantitative methods. When serum or BSK is added to these types of cell structures they appear to rupture, releasing cytoplasmic contents, unlike the emergence of intact spirochaete-shaped cells that we observed (Fig. $2 \mathrm{~B}, \mathrm{C})$.

Morphological changes by $B$. burgdorferi cells in response to adverse environmental conditions have been described by others (Barbour \& Hayes, 1986; Brorson \& Brorson, 1997, 1998a; Burgdorfer \& Hayes, 1989; Kersten et al., 1995 ; Preac Mursic et al., 1989). For example, the formation of vesicles or blebs and gemmae 
has been shown to occur when cells are exposed to physiological stress such as changes in $\mathrm{pH}$, depletion of metabolites, and ageing (Burgdorfer \& Hayes, 1989) or exposure to antibiotics (Kersten et al., 1995; Preac Mursic et al., 1989). Little is known about the physiological role of these forms, although blebs and gemmae have been shown to contain DNA (Garon et al., 1989) and may be involved in the exchange of genetic information. Unlike cyst-forms, blebs and gemmae have not been shown to be viable, capable of transforming back into motile, vegetative cells. We have also observed blebs and gemmae in our cultures, particularly when cells are exposed to antibiotics and extreme $\mathrm{pH}$ stress, but it is clear that these vesicles are not cysts.

In addition to loss of motility and cyst formation, $B$. burgdorferi cells responded to serum starvation by inducing the synthesis of a number of proteins (Table 2). Using monoclonal antibodies to well-characterized antigens, we identified one of the starvation-induced proteins (SSP o; see Table 2). It appears that SSP o (OspA) synthesis increases about twofold when compared to cells incubated in RPMI $+\mathrm{S}$. The upregulation of OspA during serum starvation is not surprising since OspA is the major outer-membrane protein detected in unfed ticks. Additionally, it has been suggested that OspA and OspC are inversely regulated by nutrient availability (Das et al., 1997; Schwan et al., 1995). However, an increased accumulation of OspA was not detected by Western blot analysis (Fig. 4). This may be due to either increased turnover of OspA during cyst formation or the loss of OspA-containing membrane during cyst formation (Fig. 2). We successfully identified another SSP (SSP s) by MALDI-MS as a homologue of VlsE, a protein shown to be involved in antigenic variation of B. burgdorferi cells (Zhang et al., 1997). VlsE and its role in starvation-induced forms warrant further study. It is tempting to speculate that some of the proteins upregulated during serum starvation regulate this response.

Bacteria have evolved elaborate strategies that enable them to survive periods of starvation (Siegele \& Kolter, 1992). Examples of morphological changes that occur in response to starvation include the formation of endospores (Losick \& Youngman, 1984), ultramicrocells (Kjelleberg et al., 1987) and fruiting bodies (Kaiser, 1984). Bacterial cells have also been shown to alter fatty acid composition, surface properties and cell walls in response to starvation (Kjelleberg et al., 1987; Nyström \& Kjelleberg, 1989). Further, the carbon-starvation response of Vibrio sp. strain S14 has been shown to be dependent upon a spoT homologue (Ostling et al., 1996). As in B. burgdorferi cyst formation, the Vibrio S14 carbon-starvation response (or ultramicrocell formation) involves: (1) loss of motility, (2) change in morphology to a spherical form, and (3) expression of a number of genes. Burgdorfer \& Hayes (1989) suggested that cyst formation of B. burgdorferi cells may be part of a complex developmental cycle. An adaptive response by B. burgdorferi to periods of starvation would seem to be essential for an organism that lacks critical bio- synthetic pathways and depends largely on its environment for metabolites.

The response of bacteria to fatty acid starvation is not well known, as most bacteria studied are capable of fatty acid synthesis. Escherichia coli responds to fatty acid starvation by accumulating spoT-dependent guanosine tetraphosphate (ppGpp) and inhibiting stable rRNA synthesis (Seyfzadeh et al., 1993). ppGpp is an effector molecule involved in the physiological response of some bacteria to nutritional stress (Cashel \& Rudd, 1987; Nyström, 1993). The SpoT protein is a bifunctional enzyme involved in the degradation and synthesis of ppGpp in bacteria (Cashel \& Rudd, 1987). Interestingly, the genome of B. burgdorferi contains a putative spoT gene (Fraser et al., 1997). We are currently investigating the possibility that the putative spoT is involved in the regulation of the serum-starvationinduced proteins described in this study.

Cysts have been observed in vitro in human CSF (Brorson \& Brorson, 1998a) and in vivo in the tissues of Lyme-disease-infected humans (Aberer et al., 1997; Hulinska et al., 1994). It is not known whether the cysts observed in those studies are the same as the cysts described in this report. However, if viable cysts form in the body, they may represent a strategy that facilitates the survival of $B$. burgdorferi cells during nutritionally adverse conditions in host tissues. By forming cysts, it is also conceivable that $B$. burgdorferi cells evade detection by the immune system. We have not yet investigated the surface properties of cysts; thus, the clinical significance of these forms is not clear. However, Hulinska et al. (1994) demonstrated that the surface of cyst-forms found in the erythema chronicum migrans of infected-human tissue was non-reactive to antibodies against OspA, whereas the content of the cysts did react with OspA. It would be interesting to determine whether the surfaces of cysts described in this study are antigenically different from the surface of vegetative cells.

This study presents data describing the physiological response of $B$. burgdorferi to a specific starvation. Our data suggest that B. burgdorferi cells, although possessing a small genome and extremely limited biosynthetic capabilities, rapidly respond to conditions of serum starvation by inducing a programme that involves loss of motility, change in morphology, and rapid induction of proteins.

\section{ACKNOWLEDGEMENTS}

We thank Barbara Johnson for supplying monoclonal antibodies, Mario Philipp for supplying monkey sera, and Thomas Mather for supplying human sera used in this study. This study was supported by Public Health Service grant AI37230 to D.R.N.

\section{REFERENCES}

Aberer, E., Koszik, F. \& Silberer, M. (1997). Why is chronic Lyme borreliosis chronic? Clin Infect Dis 25 (Suppl 1), S64-S70.

Akins, D. R., Bourell, K. W., Caimano, M. J., Norgard, M. V. \& Radolf, J. D. (1998). A new animal model for studying Lyme 
disease spirochetes in a mammalian host adapted state. $J$ Clin Invest 101, 2240-2250.

American Public Health Association (1975). Standard Methods for the Examination of Water and Wastewater, 14th edn, pp. 923-927. New York: American Public Health Association.

Barbour, A. G. (1984). Isolation and cultivation of Lyme disease spirochetes. Yale J Biol Med 57, 521-525.

Barbour, A. \& Hayes, S. F. (1986). Biology of Borrelia species. Microbiol Rev 50, 381-400.

Bradford, M. M. (1976). A rapid and sensitive method for the quantitation of microgram quantities of protein utilizing the principle of protein-dye binding. Anal Biochem 72, 248-254.

Brorson, O. \& Brorson, S. H. (1997). Transformation of cystic forms of Borrelia burgdorferi to normal, motile spirochetes. Infection 25, 240-245.

Brorson, O. \& Brorson, S. H. (1998a). In vitro conversion of Borrelia burgdorferi to cystic forms in spinal fluid, and transformation to mobile spirochetes by incubation in BSK-H media. Infection 26, 144-150.

Brorson, O. \& Brorson, S.H. (1998b). A rapid method for generation of cystic forms of Borrelia burgdorferi, and their reversal to mobile spirochetes. APMIS 106, 1131-1141.

Burgdorfer, W. \& Hayes, S. F. (1989). Vector-spirochete relationship in louse-borne and tickborne borreliosis with emphasis on Lyme disease. In Advances of Disease Vector Research, pp. 127-150. Edited by K. F. Harris. New York: Springer.

Burgdorfer, W., Barbour, A. G., Hayes, S. F., Benach, J. L., Grunwaldt, E. \& Davis, J. P. (1982). Lyme disease, a tick-borne spirochetosis? Science 216, 1317-1319.

Carreiro, M. M., Laux, D. C. \& Nelson, D. R. (1990). Characterization of the heat shock response and identification of heat shock antigens of B. burgdorferi. Infect Immun 58, 2186-2191.

Cashel, M. \& Rudd, K. E. (1987). The stringent response. In Escherichia coli and Salmonella typhimurium: Cellular and Molecular Biology, pp. 1410-1438. Edited by F. C. Neidhardt and others. Washington, DC: American Society for Microbiology.

Das, S., Barthold, S. W., Giles, S. S., Montgomery, R. R., Telford, S. R., III \& Fikrig, E. (1997). Temporal pattern of Borrelia burgdorferi $\mathrm{p} 21$ expression in ticks and mammalian hosts. J Clin Invest 99, 987-995.

Fikrig, E., Feng, W., Aversa, J., Schoen, R. T. \& Flavell, R. A. (1998). Differential expression of Borrelia burgdorferi genes during erythema migrans and Lyme arthritis. J Infect Dis 178, 1198-1201.

Fraser, C. M., Casjens, S., Huang, W. M. \& 35 other authors (1997). Genomic sequence of a Lyme disease spirochaete, Borrelia burgdorferi. Nature 390, 580-586.

Garcia, T., Otto, K., Kjelleberg, S. \& Nelson, D. R. (1997). Growth of Vibrio anguillarum in salmon intestinal mucus. Appl Environ Microbiol 63, 1034-1039.

Garon, C. F., Dorward, D. W. \& Corwin, M. D. (1989). Structural features of Borrelia burgdorferi - the Lyme disease spirochete: silver staining for nucleic acids. Scanning Microsc (Suppl 3), 109-115.

Girouard, L., Laux, D. C., Jindal, S. \& Nelson, D. R. (1993). Immune recognition of human Hsp60 by Lyme disease patient sera. Microb Pathog 14, 287-297.

Hulinska, D., Bartak, P., Hercogova, J., Hancil, J., Basta, J. \& Schramlova, J. (1994). Electron microscopy of Langerhans cells and Borrelia burgdorferi in Lyme disease patients. Zentbl Bakteriol 280, 348-359.

Johnson, R. C. \& Norton Hughes, C. A. (1992). The Genus Borrelia.
In The Prokaryotes: a Handbook on Habitats, Isolation and Identification of Bacteria, pp. 3560-3566. Edited by M. P. Starr, H. Stolp, A. Trüper \& H. G. Balows. New York: Springer.

Kaiser, D. (1984). Regulation of multicellular development in Myxobacteria. In Microbial Development, pp. 197-218. Edited by R. Losick \& L. Shapiro. Cold Spring Harbor, NY: Cold Spring Harbor Laboratory.

Kersten, A., Poitscheck, S., Rauch, S. \& Aberer, E. (1995). Effects of penicillin, ceftriaxone, and doxycycline on morphology of Borrelia burgdorferi. Antimicrob Agents Chemother 39, 1127-1133.

Kjelleberg, S., Hermansson, P., Marden, P. \& Jones, G. W. (1987). The transient phase between growth and nongrowth of heterotrophic bacteria, with emphasis on the marine environment. Annu Rev Microbiol 41, 25-49.

Laemmli, U. K. (1970). Cleavage of structural proteins during assembly of the head of bacteriophage T4. Nature 227, 680-685.

Losick, R. \& Youngman, P. (1984). Endospore formation in Bacillus. In Microbial Development, pp. 63-88. Edited by R. Losick \& L. Shapiro. Cold Spring Harbor, NY: Cold Spring Harbor Laboratory.

Nyström, T. (1993). Global systems approach to the physiology of the starved cell. In Starvation in Bacteria, pp. 129-150. Edited by S. Kjelleberg. New York: Plenum.

Nyström, T. \& Kjelleberg, S. (1989). Role of protein synthesis in the cell division and starvation-induced resistance to autolysis of a marine Vibrio during the initial phases of starvation. J Gen Microbiol 135, 1599-1606.

Ostling, J., Holmquist, L. \& Kjelleberg, S. (1996). Global analysis of the carbon starvation response of a marine Vibrio species with disruptions in genes homologous to relA and spoT. J Bacteriol 178, 4901-4908.

Philipp, M. T., Aydintug, M. K., Bohm, R. P. \& 7 other authors (1993). Early and early disseminated phases of Lyme disease in the rhesus monkey: a model for infection in humans. Infect Immun 61, 3047-3059.

Preac Mursic, V., Weber, K., Pfister, H. W., Wilske, B., Gross, B., Baumann, A. \& Prokop, J. (1989). Formation and cultivation of Borrelia burgdorferi spheroplast L-form variants. Infection 17, 355-359.

Roberts, E. D., Bohm, R. P., Lowrie, R. C., Habicht, G., Katona, L., Piesman, J. \& Philipp, M. (1998). Pathogenesis of Lyme neuroborreliosis in the rhesus monkey: the early disseminated and chronic phases of disease in the peripheral nervous system. $J$ Infect Dis 178, 722-732.

Schwan, T. G., Piesman, J., Golde, W. T., Dolan, M. C. \& Rosa, P. A. (1995). Induction of an outer surface protein on Borrelia burgdorferi during tick feeding. Proc Natl Acad Sci USA 92, 2909-2913.

Scorpio, A., Johnson, P., Laquerre, A. \& Nelson, D. R. (1994). Subcellular localization and chaperone functions of Hsp60 and Hsp70 in Borrelia burgdorferi. J Bacteriol 176, 6449-6456.

Seyfzadeh, M., Keener, J. \& Nomura, M. (1993). spoT-dependent accumulation of guanosine tetraphosphate in response to fatty acid starvation in Escherichia coli. Proc Natl Acad Sci USA 90, 11004-11008.

Siegele, D. A. \& Kolter, R. (1992). Life after log. J Bacteriol 174, 345-348.

de Silva, A. M. \& Fikrig, E. (1997). Arthropod and host-specific gene expression by Borrelia burgdorferi. J Clin Invest 99, 377-379. de Silva, A. M., Telford, S. R., Brunet, L. R., Barthold, S. W. \& Fikrig, E. (1996). Borrelia burgdorferi OspA is an arthropod- 
specific transmission-blocking Lyme disease vaccine. J Exp Med 183, 271-275.

Steere, A. C. (1989). Lyme disease. N Engl J Med 321, 586-596.

Suk, K., Das, S., Sun, W., Jwang, B., Barthold, S. W., Flavell, R. A. \& Fikrig, E. (1995). Borrelia burgdorferi genes selectively expressed in the infected host. Proc Natl Acad Sci USA 92, 4269-4273.

Towbin, H., Staehelin, T. \& Gordon, J. (1979). Electrophoretic transfer of proteins from polyacrylamide gels to nitrocellulose sheets: procedure and some applications. Proc Natl Acad Sci USA 76, 4350-4354.

Williams, K. R., Samandar, S. M., Stone, K. L., Saylor, M. \& Rush,
J. (1996). Matrix assisted-laser desorption ionization mass spectrometry as a complement to internal protein sequencing. In The Protein Protocols Handbook, pp. 541-555. Edited by J. M. Walker. Totowa: Humana Press.

Zhang, J.-R., Hardham, J. M., Barbour, A. G. \& Norris, S. J. (1997). Antigenic variation in Lyme disease borreliae by promiscuous recombination of VMP-like sequence cassettes. Cell 89, 275-285.

Received 22 June 1999; revised 13 September 1999; accepted 28 September 1999. 